\title{
A15 牛用駆虫剤イベルメクチンの䔬分解性昆虫に及ぼす影響
}

○岩佐光啓 ${ }^{1}$ ，中村絵理 ${ }^{1}$ ，丸山真澄 ${ }^{1}$ ，山下伸夫 ${ }^{2}$ ( ${ }^{1}$ 帯広畜大・昆虫, ${ }^{2}$ 東北農業研究センター) Ivermectin pour-on for cattle: Effects on some coprophagous insects Iwasa, M., Nakamura, E., Maruyama, M., Yamashita, N.

駆蛴イベルメクチンは，牛の内部寄生線虫の駆虫とノサシバエなどの外部寄生虫の駆除に効果があるとされてい

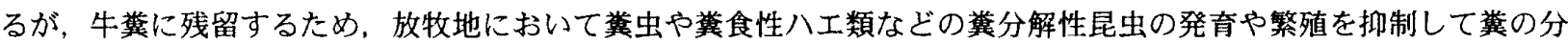
解消失を遅らせることが海外で報告されている．日本で広く使用されているイベルメクチンをポアオン法で5頭の牛 に処理し，それらの䔬を用いて翼食性八工類と蕒虫類の発育，発生，羽化等に及ぼす影響及び牛䔬の有機物消失に及 ぼす影響を調べた，マエカドコエンマコガネは，野外で処理区の瓷に誘引されやすく，育览球をより多く形成したが， 羽化率は低下した. キタミドリイエバエとノサシバエの幼虫は, 処理区では投与後 $1,3,7,14$ 日目の犦ですべて死亡し,

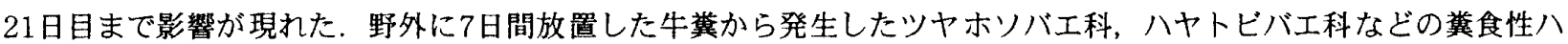
工類の個体数は，処理区で著しく減少した．野外に7日間放置した牛粪の有機物残存率は，対照区より処理区で高く なった。

\section{A16 不快動物はなぜ不快なのか}

茂木幹義（佐賀医科大学）

Why nuisances are nuisances?

Mogi, M.

直接的な害がない動物に対する大きな恐れ・実際の害に不相応に大きな恐れは恐怖症Phobiaとして扱われ，精神 医学での治療対象になってきた，それほど極端でなくても，多くの人は特定の動物に対して嫌悪感や不快感を持って いる. 比較的多くの人に好まれない上に接する機会も多い動物が不快動物とされ，個人的な排除・駆除の対象，時に は公的な対策の対象になる，不快動物に対する合理的な対応は，生物との共生を実現する上で避けられない重要な問 題であろう。しかし不快動物はなぜ不快なのか，なぜ排除されねばならないのかという問題が科学的に取り上げられ ることはほとんどなかった。本講演では，この問題を考えるきっかけになることを期待して，佐賀でのアンケート調 查の結果を紹介し，また人間精神の根幹に触れる奥深い問題であることを指摘したい. 